\title{
OPTIMIZATION OF HYDRATED LIME PUTTIES AND LIME MORTARS USING NOPAL PECTIN FOR CONSERVATION OF CULTURAL HERITAGE
}

\author{
ANGÉLICA PÉREZ RAMOS ${ }^{1}$, JOSE LUZ GONZÁLEZ CHÁVEZ ${ }^{2}$, LUIS FERNANDO GUERRERO BACA ${ }^{3}$, \\ MIGUEL ÁNGEL SÁNCHEZ ESPINOSA ${ }^{1} \&$ ANAÍ CHIKEN SORIANO ${ }^{2}$ \\ ${ }^{1}$ Iberomaerican University Puebla, Mexico \\ ${ }^{2}$ National Autonomus University of Mexico (UNAM), Mexico \\ ${ }^{3}$ Metropolitan Autonomus University of Xochimilco (UAM-X), Mexico
}

\begin{abstract}
Hydrated lime as a putty has had a very important role as a binder for mortars and plasters in which hundreds of years of archeological, artistic, and historical heritage have been preserved. There is evidence that the Maya improved the properties of their mortars by adding gum from different Mayan tree barks during lime hydration process. This interdisciplinary investigation made it possible to demonstrate that nopal mucilage can optimize slaked lime properties during lime hydration process, starting from the idea that the cactus produces both, gums and mucilage. During the chemical experimentation, it was possible to isolate the main component of the optimal physical and chemical interaction between lime and nopal mucilage. The main objectives of this research were to rediscover the value of an ancestral production technique, to position hydrated lime putty as an attractive product to builders that work with historic structures by optimizing its properties and lime mortars' behavior, and to reduce hydrated lime putties production time, specifically by speeding up the aging process from months to hours. Rheological and mechanical experiments succeeded in proving that the pectin of the nopal has a direct influence on the slaking lime process, improving lime putties and mortars' properties. Lime putties and lime mortar specimens were tested in XRD (X-Ray Diffraction) and SEM (Scanning Electron Microscope 7800) where crystallographic changes related to the optimization of the properties of lime mortars and lime putties were verified. The results established a new paradigm for the slaking lime process as the main production phase for lime putties and their mortars. Nopal pectin improves lime putties and lime mortars' plasticity, mechanical strength and proclivity to carbonation, while it also produces a reduction in capillarity absorption and mortar cracks.
\end{abstract}

Keywords: lime mortars, slaking lime, lime putties, nopal pectin, rheological, mechanical, lime properties, hydrated lime, mortar properties, Mayan.

\section{INTRODUCTION}

It is well known that hydrated lime is one of the basic materials in the archaeological and architectural legacy of the whole world [1].

Since ancient times, hydrated lime could be obtained through different procedures that depended mainly on culture. One of the most common procedures consisted on hydrating quicklime using a great amount of water (greater than necessary) in order to obtain hydrated lime putty. The process begins when the limestone $\left(\mathrm{CaCO}_{3}\right)$ is calcined at $1,100^{\circ} \mathrm{C}$ to generate quicklime $(\mathrm{CaO})$ that, when cooled, is added to water. This causes an exothermic reaction (up to $100^{\circ} \mathrm{C}$ ) followed by a constant stirring phase that after about an hour, results in hydrated lime putty $\left(\mathrm{Ca}(\mathrm{OH})_{2}\right)[1]$, [2].

When hydrated lime putty is obtained, it must remain under a mirror of water to protect it from carbonation. This phase is known as the aging period of hydrated lime putty and the purpose is to optimize its properties. The longer the time it remains in this phase, the better the properties it develops [2]-[5].

There is a large number of investigations that have already demonstrated the chemical and physical evolution of calcium hydroxide upon aging of lime putty and its influence on 
lime properties [3], [4]. Basically, an aging process provides better plasticity for lime putties and mortars. In later investigations it was also proved that not only putties, but mortars as well, acquire a better plasticity and strengthen behavior [4], [5].

In our country, the procedure of hydrating quicklime $(\mathrm{CaO})$ at construction sites currently takes place in large rectangular brick containers where, in addition, the aging of hydrated lime putties $\left(\mathrm{Ca}(\mathrm{OH})_{2}\right)$ is carried out. Unfortunately, the traditional process of quicklime hydration has been neglected due to the long aging period of lime putties, which takes at least 2 months as indicated by the authorities. This long aging process can have a negative impact on a project's budget; therefore, many builders would rather use other binders - such as cement - that are incompatible with traditional construction systems. This doesn't only affect the results of restoration work on historic buildings, but it also contributes to accelerating the loss of an ancestral production technique and of the material itself. As part of this loss, the lime slaking technique is sometimes negatively altered and lime putties hydrated at the construction site lack adequate rheological and mechanical properties. This results in constant empirical experiments with natural additives in order to improve lime and mortar properties for conservation purposes [1], [6], [7].

\section{THE ANCIENT MAYAN TECHNIQUE}

Mayans were known experts in lime production for construction purposes. In recent investigations, extensive areas of limestone quarries have been located, which might show how essential of a material lime was for the city-states of the Mayan civilization. According to archeological findings, the use of lime as a stone and as a binder allowed them to build famous arches and temple crests, while they also developed lime mortars with extraordinary properties. The use of lime as a binder, implied a specific form of production that included the gum from the bark of some trees to obtain hydrated lime putties that optimized their mortars' properties [7].

As it has been exposed, the phase of quicklime hydration is essential to obtain a lime putty with good binding properties. In the past, the Mayans from the northern region used a slightly different procedure to obtain lime putties. This procedure did not only consist on adding water to the quicklime $(\mathrm{CaO})$, but also adding the bark of some trees into the water so that their gums exuded and thus serve as a hydration agent.

Gum from tree barks improved plasticity, cohesion, strength and porosity in mortars that were prepared using the resulting hydrated lime putty as a binder. This improvement was explained as an increase in the solubility of quicklime $(\mathrm{CaO})$, caused by monosaccharides as main components of gums from the bark of the trees [1], [7], [8].

\section{THE OBJECTIVE OF THIS INVESTIGATION}

Based on the Mayan technique for lime hydration, it was proposed to use nopal mucilage in the process, considering its similarities in chemical composition - such as polysaccharides with the gums of the barks of the Mayan trees.

Besides being affordable for the entire population and growing practically throughout the entire Mexican territory, nopal mucilage has been used as an additive during the formulation of mortars for restoration work as it has been demonstrated that it optimizes certain properties of the mortars in which it is used. Since nopal is mainly composed by polysaccharides, it was expected to have an influence at the early stage of lime putties and mortars' production - the quicklime hydration phase - as a hydrating agent [6], [9].

In line with the above, the main purpose if this research was to demonstrate that nopal mucilage can work as a hydration agent for quicklime $(\mathrm{CaO})$ to improve the properties of slaked lime putties $\left(\mathrm{Ca}(\mathrm{OH})_{2}\right)[6],[9],[10]$. 
During the first experimental phase in the chemistry laboratory, it was discovered that, in addition to polysaccharides being contained in nopal mucilage, a specific substance, galacturonic acid, was the one responsible for enabling the successful interaction between nopal mucilage and quicklime $(\mathrm{CaO})$. This substance was isolated to test it as a hydrating agent for quicklime $(\mathrm{CaO})$ in parallel with nopal mucilage and water. The results were focused on the use of nopal pectin as a hydration agent compared to water [11].

\subsection{Material and methods}

Galacturonic acid was isolated from cactus pectin. A solution with a specific concentration was prepared with this substance to enable the hydration of quicklime $(\mathrm{CaO})$ and to obtain hydrated lime putty $\left(\mathrm{Ca}(\mathrm{OH})_{2}\right)$ in nopal pectin [6], [11].

The lime hydration process was carried out using 1:2 proportion by weight of the ratio between quicklime and the pectin solution. At the same time, quicklime $(\mathrm{CaO})$ was hydrated in water as a control solution to compare the behavior of both products. The hydration process of the quicklime $(\mathrm{CaO})$ in each solution was carried out with constant stirring for 1 hour. Once the putties were obtained, they were protected with a mirror of water to avoid carbonation, and finally experimentation with each of them was carried out [6].

Lime putties were analyzed in different phases, from their recent production (one hour old) through all the different periods of their aging process [6]. The lime pastes were analyzed at 28 days and then at 400 days of aging. The analysis sought to characterize the crystallographic behavior, for which a 7800 SEM was used. The physical phases were analyzed in an XRD Bruker D8 and the Abrams cone was used to determine the plasticity of the lime putties as shown in Figs 1-3 [6].
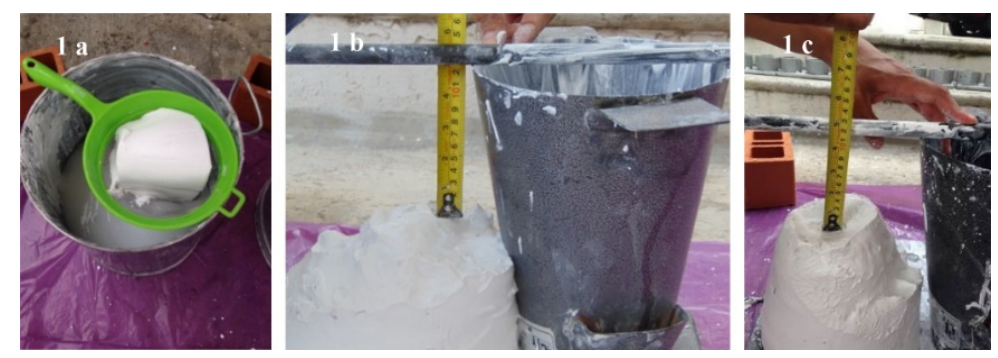

Figure 1: (a) Lime putty taken from its container during aging phase; (b) and (c) Determination of plasticity using Abrams cone.
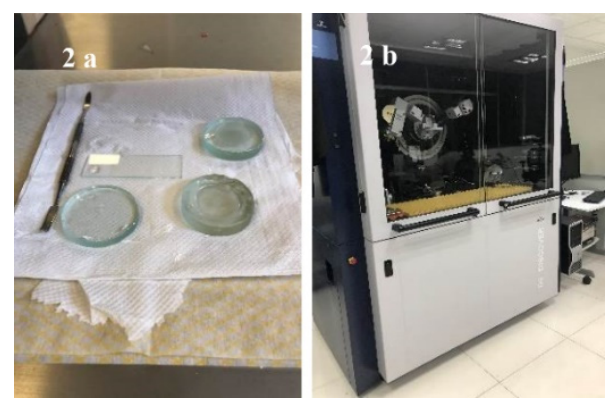

Figure 2: (a) and (b) XRD and lab material for testing lime putties. 


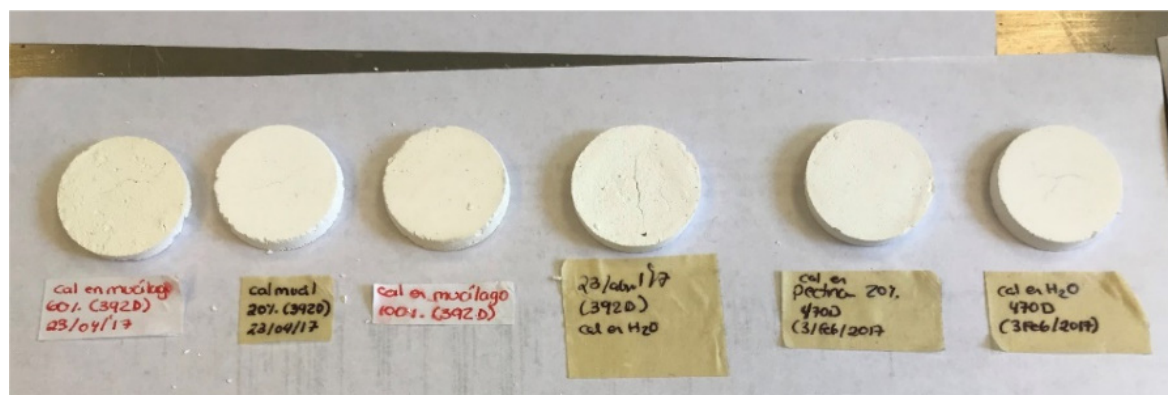

Figure 3: Different lime putty samples to be analyzed in the XRD at different periods of aging.

Different mortar samples were prepared with each type of lime putty produced in the two selected aging periods. The analysis of the mortars had the objective of characterizing their mechanical and rheological behavior based mainly on the ASTM-C-109 and NMX-C-0821974 standard. The mortar specimens were also analyzed to determine their propensity for carbonation using phenolphthalein and the calculation of their capillary absorption capacity was based on the NORMAL 11/85 standard [6].

The mortars were formulated using a ratio of 1:3 by weight, with regard to the lime and arid ratio. This ratio was determined after several previous experiments with different ratios. The procedure for preparing the mortars and their specimens (cubic specimens about 125 $\mathrm{cm}^{3}$ ), was based on ASTM C270 - 02, ASTM D752000 and ASTM C-109 standards mainly (Fig. 4(a)-4(g)) [6].
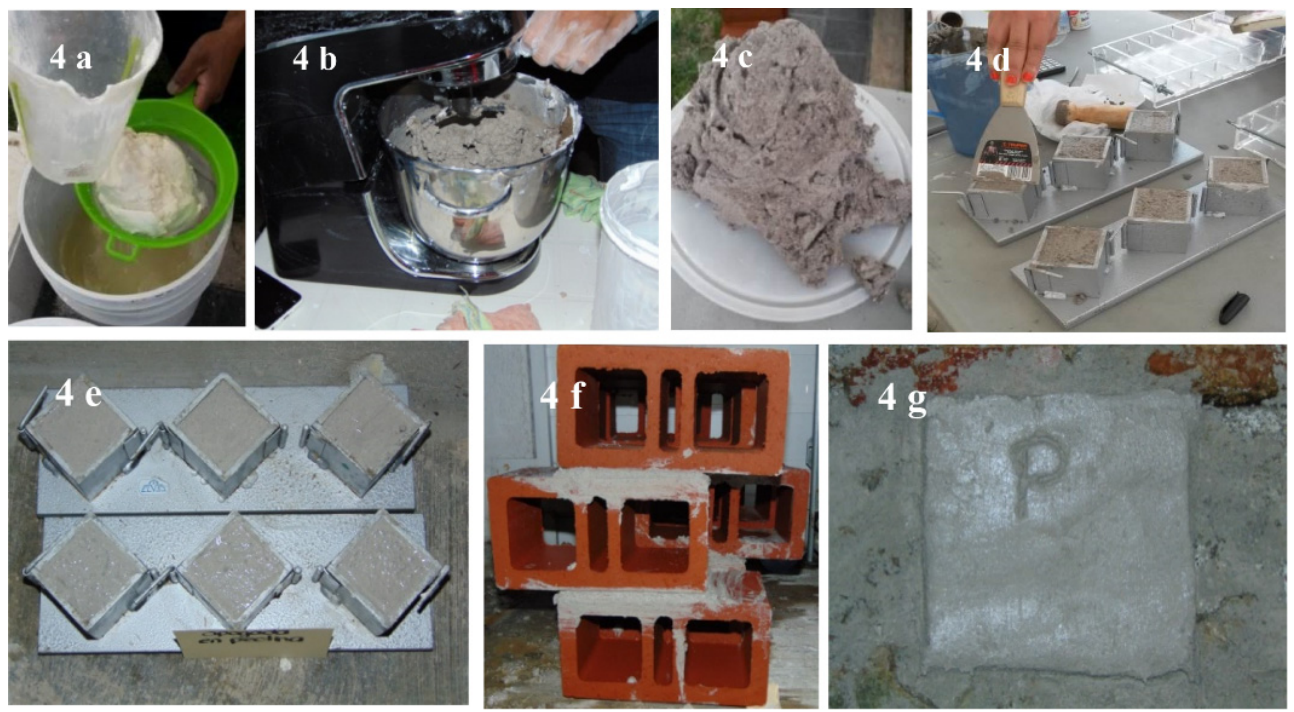

Figure 4: (a) Lime putty taken from its container during aging phase; (b) and (c) Lime mortar preparation process; (d) and (e) Cubic specimens for experimentation; (f) Specimens to test the adhesion capacity of mortars; and (g) Specimens prepared to measure cracking control. 
The mortar specimens were subjected to different analyses that would measure their behavior at 45, 100 and 200 days of aging. The capacity of resistance to compression and adhesion of the mortars were evaluated using a manual digital press type machine model E657-2, their plasticity was measured by using the Abrams cone, the capillary absorption capacity was measured with the help of an Ohaus Precision Balance in accordance with the procedure established in the NORMAL 11/85 standard, and finally the mortars' availability to carbonation was determined by using the phenolphthalein method [6].

\section{RESULTS AND DISCUSSION}

The results of the different tests carried out on the putties and the mortars that were manufactured with them made it possible to conclude that the pectin extracted from the nopal mucilage improves both the putties' rheological properties and the early carbonation phases. The diffractograms showed calcite phases in lime putty samples that had been hydrated in nopal pectin for only 28 days, which suggests the immediate start of the carbonation process. In contrast, in the putties that were hydrated in water, only portlandite phases could be detected, that is, without initiating the carbonation process. Both putties were exposed to $\mathrm{CO}_{2}$ for only 15 minutes while preparing to be examined on the XRD (Figs 5 and 6).

Changes in the crystalline morphology could be identified in the SEM 7800 from the first day of their manufacture in the lime putties that were hydrated with nopal pectin. The crystalline morphology tended towards flat hexagonal patterns that usually appear when the lime putties have undergone an aging process of 12 to 14 months, while in the putties that where hydrated with water, the crystalline morphology preserved the prismatic hexagonal patterns that are characteristic of a paste in the early stages of aging [6].

The observations in the SEM, showed that the crystallographic transformation during the aging process from prismatic hexagonal to flat hexagonal patterns is more evident in the putties that were hydrated in nopal pectin (Figs 7-9).

Regarding the mechanical behavior of mortars, those prepared with lime putty hydrated in nopal pectin showed an increase of $67 \%$ in resistance to compression and better plasticity than mortars prepared with lime putty hydrated in water (Fig. 10). The results presented here were obtained from specimens tested at 45, 100 and 200 days of aging [6].

Compared to the mortars that were made using lime putties hydrated in water, mortars prepared with lime putties hydrated in nopal pectin for 28 and 183 days showed a $50 \%$ reduction in their capillary absorption capacity. The evaporation of the water in the samples took place 35 minutes faster and the carbonation process was carried out $85 \%$ faster, even in the areas with less exposure to $\mathrm{CO}_{2}$ (Fig. 11(a)-11(d)). Moreover, the cracks in the mortars used as coatings showed a reduction of $50 \%$. 


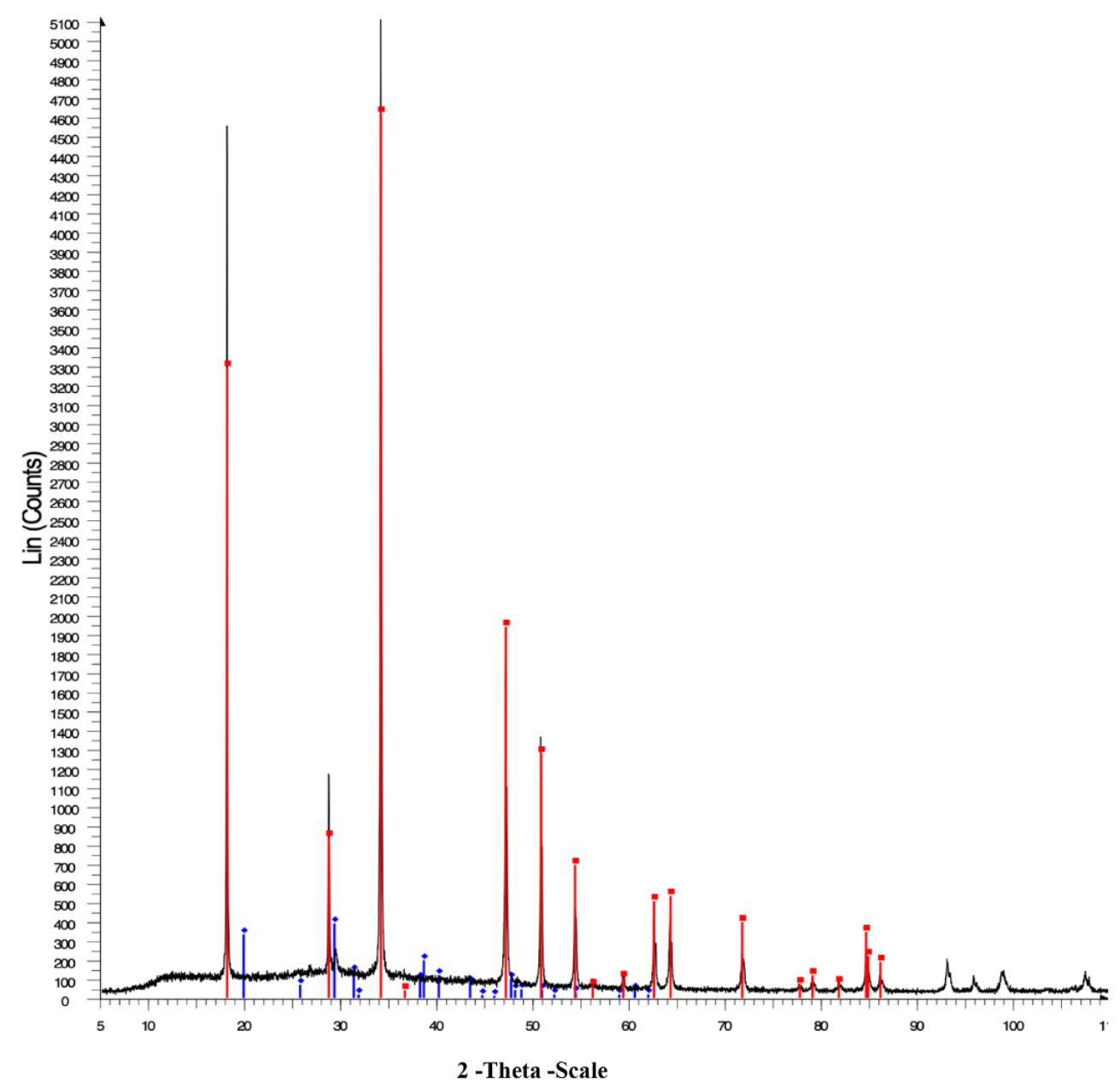

Cal-H2O22-02-18-File: Cal-H2O-22-05-18.raw-Type: Locked Coupled- Start: 5.000-

$W$ End: $109.999^{\circ}$ - Step: $0.021^{\circ}-$ Step time: $38.4 \mathrm{~s}$ - Temp.: $25^{\circ}$

Operations: Import

口 01-084-1263 C) - Calcium Hydroxide - $\mathrm{Ca}(\mathrm{OH}) 2-\mathrm{Y}: 90.34 \%$ - d x by: 1. - WL: $1.5406-$ Hexagonal - a3.59180 - b3.59180 - c4.90630 - alpha 90.000-

$00-024-0223(*)-$ Hydrophilite [NR] - CaCl2 - Y: $7.57 \%$ - d x by: 1. - WL: $1.5406-$ Orthorhombic - a $6.26100-$ b6.42900 - c4.16700 - alpha 90.000 - bet

Figure 5: Diffractogram corresponding to lime putty hydrated in water of 28 days of aging where portlandite phases were identified. 


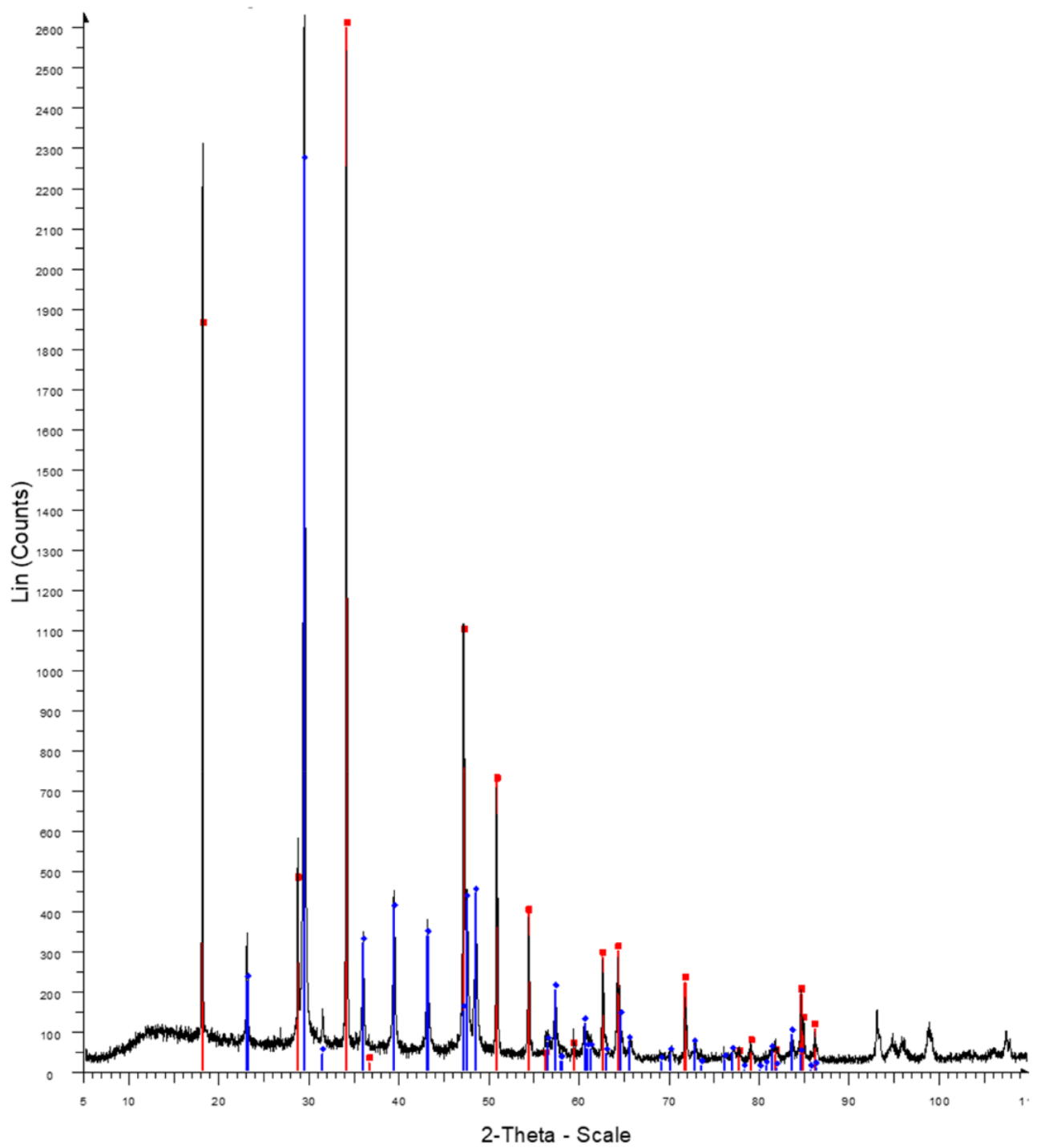

1 Cal-pectina-20\%-470D-31-feb-2017 - File: Cal-pectina-20\%-470D-31-feb-2017.rawType:Locked Coupled - Start:5.000-End: $109.999^{\circ}$-Step:0.021 Operations: import

01-084-1263 (c)- Calcium Hydroxide- $\mathrm{Ca}(\mathrm{OH}) 2-\mathrm{Y}: 98.80 \%$-dxby: 1-WL:1.5406-Hexagonal-a 3.59180-b 3.59180-c4.90630 alpha 90.000-

01-072-1937 (C)- Calcite CaCO3-Y: 86.06\% - dxby 1. - WL:1.5406- Rhombo. H. axes -a 4.99400-b-4.99400 - c17.80100 - Alpha 90.000 -beta 9

Figure 6: Diffractogram corresponding to lime putty hydrated in nopal pectin of 28 days of aging where calcite phases were identified. 


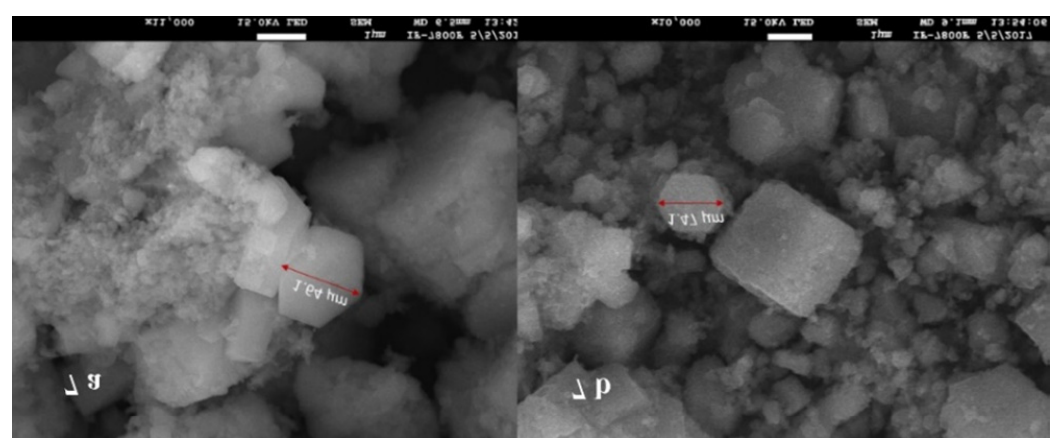

Figure 7: (a) SEM image corresponding to lime putty slaked in nopal pectin at 28 days; and (b) SEM image corresponding to lime putty hydrated in water at 28 days. In both images, crystallographic structures of prismatic hexagonal morphology micrometric size can be identified.

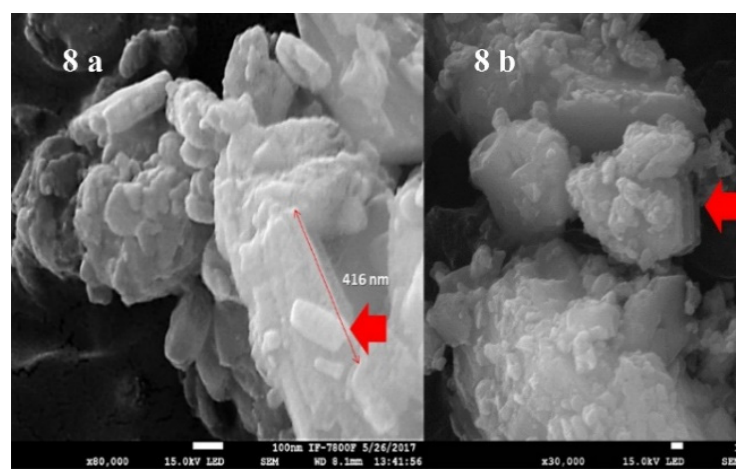

Figure 8: (a) SEM image corresponding to lime putty slaked in nopal pectin at 28 days; and (b) SEM image corresponding to lime putty hydrated in water at 28 days. In both images, micrometric sized crystallographic structures of prismatic hexagonal morphology can be identified.

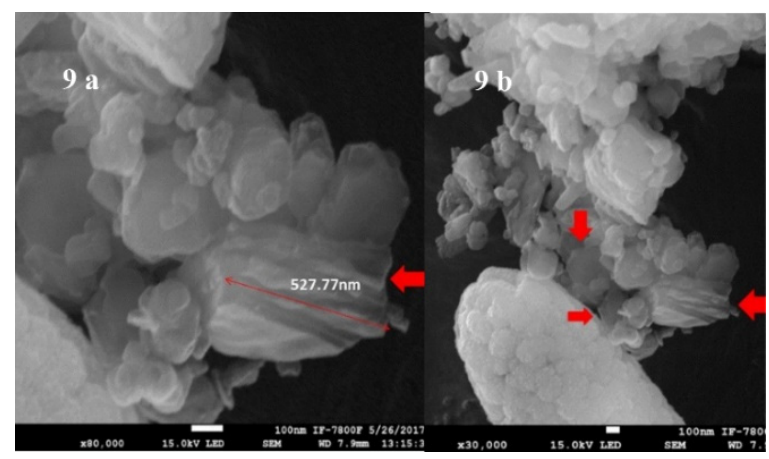

Figure 9: (a) and (b) Both SEM images show lime putty hydrated in water for 110 days. Nanosized hexagonal plate patterns can be identified in the two pictures. 

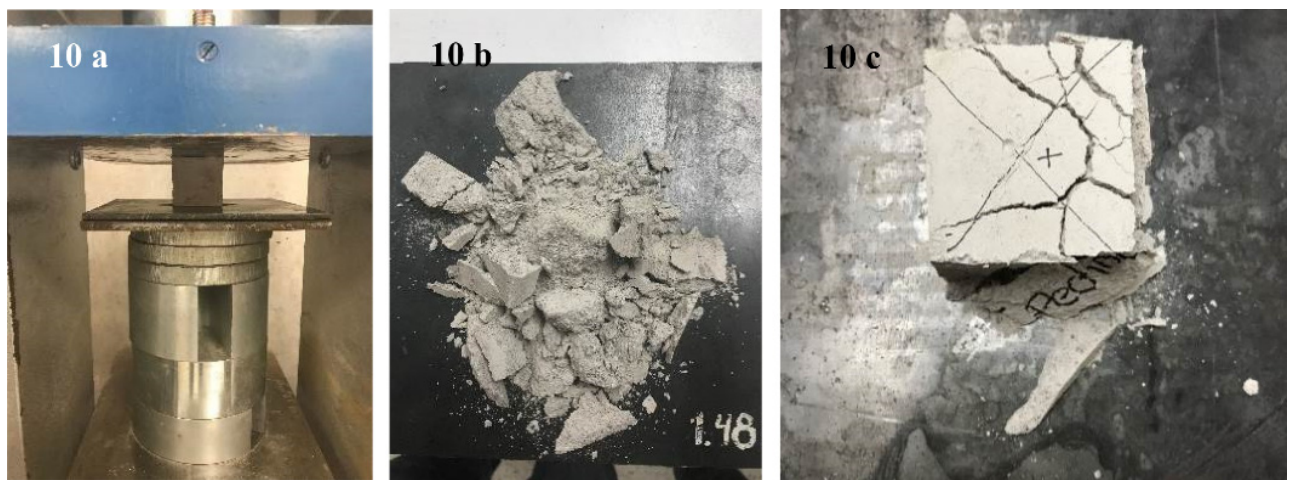

Figure 10: (a) Mortar specimen in the machine to test its compressive strength and (b) and (c) Compression tested mortar specimens.
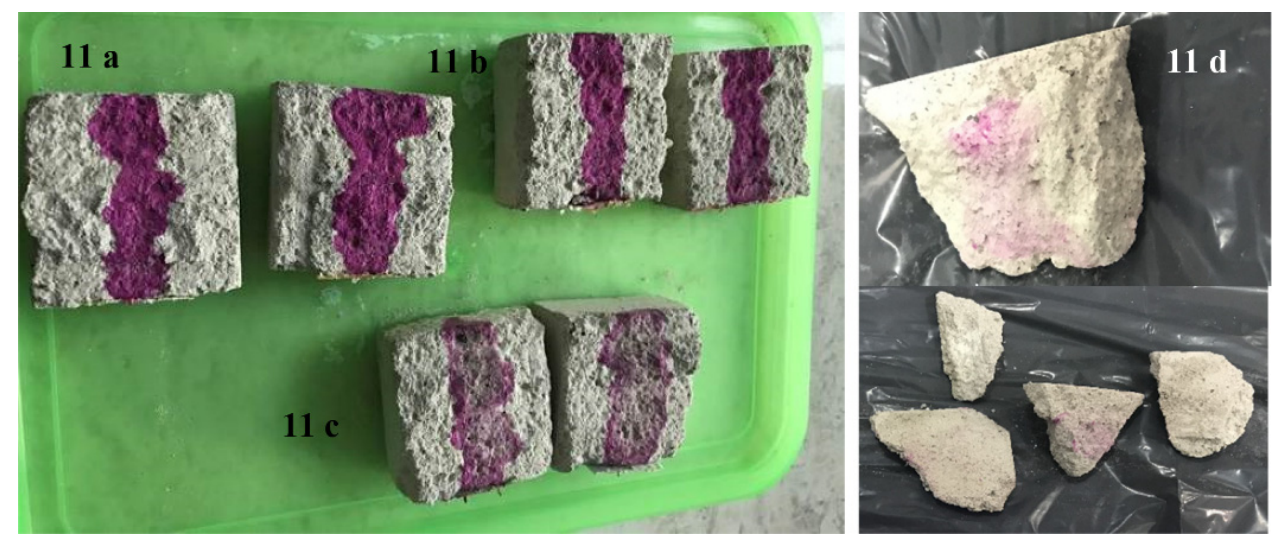

Figure 11: Mortar specimens tested for phenolphthalein to determine their capacity for carbonation. (a) and (b). In images (a) and (b) the magenta of phenolphthalein in the internal faces of the specimens indicate a lack of carbonate; (c) The faded magenta shows partial carbonation of the internal faces of these mortar specimens; and (d) The magenta color is almost imperceptible, which reflects a total carbonation of the internal face of the mortar specimen that used slaked lime putty in nopal pectin.

\section{CONCLUSION}

Nopal pectin as a hydrating agent in concentrated solutions significantly improves plasticity and makes the lime putties more reactive to carbonation when calcite phases occur at very early stages, as shown in the corresponding diffractograms. The SEM images demonstrated that there is a true evolution in the crystalline morphology from prismatic hexagonal to flat hexagonal patterns and a much more significant reduction of micrometric to nanometric dimensions in lime putties that have been hydrated in nopal pectin, compared to the ones that were hydrated in water. The foregoing allows us to conclude that the aging period that enables the optimization of the lime putties has been reduced by $92 \%$ using nopal pectin in solution to hydrate quicklime [6]. 
Although the properties of hydrated lime putty depend on all the phases of the production process, including the selection of the limestone and its calcination, it was concluded that the phase of quicklime hydration is not only susceptible to control, but also the most outstanding in terms of optimizing the period of aging and significantly improving the properties of the lime putty and its mortars [6].

Compared to mortars that were prepared with water-hydrated lime putty, the mortars that were prepared with lime putty hydrated in cactus pectin showed a notable increase in their adhesion and resistance to compression, greater plasticity, faster evaporation of water during capillary absorption, greater capacity for carbonation - even in areas with less exposure to $\mathrm{CO}_{2-}$, and a significant decrease in cracks in coating mortars during the carbonation process [6].

The ancient practice of slaking quicklime inherited by the Mayans can now be reproduced with a cactus that is affordable in economic and territorial terms in practically the entire country. Nopal mucilage improves the properties of slaked lime putties when it is used as a hydration agent, but it achieves greater effectiveness when its pectin is isolated and used in solutions at a specific concentration to hydrate quicklime. The reduction of the aging period of the lime slaked in nopal pectin by $92 \%$ compared to that hydrated in water could be the most attractive of all the properties that were successfully optimized, especially for builders who are involved in the restoration of historic buildings, as this significantly reduces costs and allows revaluing and rescuing a technique that is about to disappear - not without ensuring the compatibility of the construction systems that originally contain hydrated lime putty. Above all else, however, this practice rescues valuable knowledge and a constructive memory that deserves be preserved [6].

\section{ACKNOWLEDGEMENT}

To Universidad Iberoamericana Puebla, Puebla, Mexico, to which I am attached for the support of the mobility program for full time professors.

\section{REFERENCES}

[1] Barba, L. \& Villaseñor, I., La cal, historia, propiedades y usos, Instituto de Investigaciones Antropológicas, UNAM: Mexico, pp. 60-102, 2013.

[2] Rodríguez, C., Ruiz, A., Elert, K. \& Hansen, E., Crystallization and colloidal stabilization of $\mathrm{Ca}(\mathrm{OH})_{2}$ in the presence of nopal juice (Opuntia Ficus Indica), implications in architectural heritage conservation. Langmuir, American Chemical Society, 33, pp. 10936-10950, 2017. DOI: 10.1021/acs.langmuir.7b02423.

[3] Rodríguez, C., Cazalla, O., Sebastian, E., De la Torre, M. \& Cultrone, G., Aging of lime putty effects on traditional lime mortar carbonation. Journal of the American Ceramic, Society, 83(5), pp. 1070-1076, 2000.

DOI: $10.1111 /$ j.1151-2916.2000.tb01332.x.

[4] Rodríguez, C., Calcium hydroxide cristal evolution upon aging of lime putty. Journal of the American Ceramic, Society, 81(11), pp. 3032-3034, Nov. 1998.

DOI: $10.1111 /$ j.1151-2916.1998.tb02735.x.

[5] Rodríguez, C., Ruiz, E. \& Hansen, E., Nanostructure and Irreversible Colloidal Behavior of $\mathrm{Ca}(\mathrm{OH})_{2}$, Implications in Cultural Heritage, Departamento de Mineralogía y Petrología Universidad de Granada and The Getty Conservation Institute: Granada, España, 2005, pp. 10948-10957. http://www.ugr.es/ grupo179/ pdf/Rodriguez\%20Navarro\%2005.pdf. 
[6] Pérez, A., El Mucílago de Opuntia como Agente de Optimización de las Propiedades de Morteros y Pastas de Cal Apagada en la Restauración del Patrimonio Edificado. $\mathrm{PhD}$ thesis, Universidad Nacional Autónoma de México, Ciudad de México, México, 2019. 132.248.9.195/ptd2019/agosto/0794434/Index.html.

[7] Bedolla, J.A. et al., Aditivos Orgánicos en Morteros de Cal Apagada en la Edificación Histórica, Ciencia Nicolaita: México, pp. 51, 153-166, 2009. http://www.cic.umich.mx/documento/ciencia_nicolaita/2009/51/CN51-153.pdf.

[8] Carrascosa, B. \& Lorenzo, F., Estudios Previos en Morteros Tradicionales de Cal para la Evaluación de su Comportamiento Hídrico y la Idoneidad de ser Empleados en Clima Tropical, Instituto Universitario de Restauración del Patrimonio de la Universitat Politécnica de Valencia: España, 2002, pp. 55-61. https://riunet.upv.es/ bitstream/handle/10251/33046/2012_6-7_55-62.pdf?sequence=1.

[9] Pérez, A., Nopal mucilage as hydration agent of quicklime; extraction methods. Grupo Español de Conservación, International Institute of Conservation of Historic and Artistic Works: Madrid, España, pp. 189-195, 2017. https://ge-iic.com/ojs/index.php/ revista/article/view/475.

[10] Vargas, L. et al., Adhesivo de nopal en Pinturas a la Cal. Revista Salud Pública y Nutrición Edición Especial, (4), pp. 165-174, 2012. DOI: 10.29105/respyn.

[11] Chiken, A., Influencia del Mucílago de Nopal Sobre las Propiedades Fisicoquímicas de la Cal y su Aplicación para Materiales de Restauración, Facultad de Química. Master's degree thesis, Universidad Nacional Autónoma de México, UNAM, Ciudad de México, México, 2017. 132.248.9.195/ptd2017/mayo/0759816/Index.html. 